\title{
Effects of Different Kinds of Coating Materials on Properties of Flat Pressed WPC Panels
}

\section{Utjecaj različitih vrsta materijala za oblaganje na svojstva ravnih prešanih drvno-plastičnih kompozitnih ploča}

\author{
Original scientific paper • Izvorni znanstveni rad \\ Received-prispjelo: 12. 12. 2014. \\ Accepted-prihvaćeno: 5. 5. 2016. \\ UDK: $630 * 832.285 ; 630 * 829.3$ \\ doi:10.5552/drind.2016.1444
}

\begin{abstract}
The effects of different kinds of coating materials on the properties of flat pressed wood plastic composite (WPC) panels were studied in this work. Rotary-cut birch veneer, sliced oak veneer, phenolic impregnated paper, polyethylene (PE) film, and recycled polyethylene (rPE) layer were used as coating materials. One or two-side coating of WPC panels was carried out simultaneously with their flat pressing. No coupling agents were used for production of WPC. It was found that properties of flat pressed WPC panels improved by coating with all investigated coating materials. The highest values of modulus of rupture (MOR) were observed in WPC panels coated with rotary-cut birch veneer and MOR values were higher in along direction than in across direction of veneer fibers. The highest values of water resistance were observed in WPC coated with PE film or rPE layer. Coating of WPC with natural veneer leads to the decreasing of water resistance. Besides, water resistance of WPC coated with one side of natural veneer was higher in comparison with two side coated WPC panels with natural veneer. The two-side coating of WPC with phenolic impregnated paper, PE film or rPE layer leads to the decreasing of water absorption and thickness swelling.
\end{abstract}

Key words: coating materials, flat pressing, recycled polyethylene, veneer, wood plastic composites.

SAŽETAK • U radu su predstavljeni rezultati istraživanja utjecaja različitih vrsta materijala za oblaganje na svojstva ravnih prešanih drvno-plastičnih kompozitnih (WPC) ploča. Za oblaganje ploča primijenjeni su ljušteni brezov furnir, rezani hrastov furnir, fenolni impregnirani papir, polietilenska (PE) folija i reciklirani polietilen (RPE). Oblaganje WPC ploča s jedne ili s obje strane obavljeno je istodobno s prešanjem ploča. Za proizvodnju ploča nisu upotrebljavana sredstva za kondenzaciju. Utvrđeno je da su svojstva ravnih prešanih WPC ploča poboljšana oblaganjem bilo kojim navedenim ispitivanim materijalom. Najveće vrijednosti modula loma (MOR) zabilježene su za WPC ploče obložene ljuštenim brezovim furnirom. MOR vrijednosti bile su veće uzduž vlakanaca furnira nego okomito na njihov smjer . Najveća otpornost na vodu zabilježena je u ploča obloženih polietilenskom folijom i recikliranim polietilenskim slojem. Oblaganje WPC ploče prirodnim furnirom utječe na smanjenje otpornosti na vodu. Osim toga, otpornost na vodu WPC ploča obloženih s jedne strane prirodnim furnirom bila je veća nego WPC ploča obloženih prirodnim furnirom s obje strane. Dvostrano oblaganje WPC ploča fenolnim impregniranim papirom, polietilenskom folijom $i$ recikliranim polietilenskim slojem pridonosi smanjenju apsorpcije vode i debljinskog bubrenja.

Ključne riječi: materijali za oblaganje, ravno prešanje, reciklirani polietilen, furnir, drvno-plastični kompoziti

\footnotetext{
${ }^{1}$ Authors are professor and assistants at Department of Wood-Based Composites, National University of Forestry and Wood Technology of Ukraine, Lviv, Ukraine.

${ }^{1}$ Autori su profesor i asistenti Odjela za kompozite na bazi drva, Nacionalno sveučilište šumarstva i drvne tehnologije Ukrajine, Lviv, Ukrajina.
} 


\section{INTRODUCTION}

\section{UVOD}

Wood plastic composites (WPC) are universal materials with high modulus of rupture (MOR) and elasticity (MOE), internal bond strength, water resistance (Klyosov, 2007), biological resistance (Segerholm, 2012; Segerholm, 2007) and non toxicity (Lindfors and Salo, 2012). Therefore, WPC can be used in different sectors of economy and can be produced by different methods: extrusion, injection and compression molding, which depends on the configuration forms of the products and the field of their use (Klyosov, 2007). Extrusion is a predominant technology for manufacturing WPC in the USA and Europe. WPC panels can also be produced by flatpressing in hot press (Ayrilmis et al., 2011; Ayrilmis and Jarusombuti, 2011; Ayrilmis et al., 2012; Benthien and Thoemen, 2012; Kargarfard and Jahan-Latibari, 2012). Herewith, the pressing parameters depend on the type of thermoplastic materials and surface configuration. In particular, particleboards, oriented strand boards (OSB), and medium density fiberboards (MDF) are manufactured in this way (Thoemen et al., 2010).

Wood flour is usually used as the filler for the production of WPC (Winandy et al., 2004). Wood sawdust (Winandy et al., 2004), wood fiber (Benthien and Thoemen, 2012) and shavings (Segerholm, 2007) can be used, too. Moreover, except for wood particles, the agricultural residues, in particular wheat (Sardashti, 2009) and rice (Buzarovska et al., 2008; Yao, 2008) straw are often used as the filler for production of WPC. Wood flour is mainly used for the manufacture of WPC by extrusion (Winandy et al., 2004), while wood particles are used for the manufacture of WPC panels by flat-pressing (Ayrilmis et al., 2011; Ayrilmis and Jarusombuti, 2011; Ayrilmis et al., 2012; Benthien and Thoemen, 2012; Kargarfard and Jahan-Latibari, 2012).

Nearly $90 \%$ of WPC are produced in the USA by using PE (Klyosov, 2007). In Europe, the use of PE is lower - about $70 \%$; polypropylene (PP) - $11 \%$ and polyvinyl chloride $-9 \%$ (Eder, 2010). The use of these thermoplastic polymers can be explained by their low melting temperatures $\left(110-160^{\circ} \mathrm{C}\right)$. The thermal stability of wood becomes worse when higher temperatures (more than $200{ }^{\circ} \mathrm{C}$ ) are used (Klyosov, 2007). Further increasing of the temperature (over $200{ }^{\circ} \mathrm{C}$ ) causes the decomposition of wood macromolecules and negative changes of wood properties.

Maleic anhydride-grafted can be used as a coupling agent for the increase of bonds between the wood particles and polymeric material. Recycled PE in combination with UF resins were also used (Kargarfard and Jahan-Latibari, 2012). There are also various reactive groups in recycled polyesters. In particular, $\mathrm{C}=\mathrm{O}$, $-\mathrm{C}=\mathrm{C}-,-\mathrm{CH}=\mathrm{CH}_{2}$ reactive groups were found in recycled PE and PP (Moldovan et al., 2012). These groups can react with cellulose, lignin and other chemical components of wood. Therefore, no coupling agents are required for the production of WPC on the basis of recycled polyester.

However, the enhancing of mechanical properties of flat pressed WPC (in particular its outer layers) can be executed by strengthening their outer layers. For this purpose, the same coating materials, which are usually used for particleboard, can be applied, for example impregnated paper, natural veneers, laminates, paints, varnishes and other coating materials (Istek et al., 2010; Norvyda and Minelga, 2006). The possibilities of singlestage pressing of veneered particleboards were also investigated (Borysiuk et al., 2011). There were three variants of producing particleboards: variant I - singlelayer particleboard; variant II - single layer veneered particleboard produced in two stages, first $14 \mathrm{~mm}$ board was pressed, and then finished by veneer; variant III single layer veneered particleboard, manufactured in single operation. Two different types of thermoplastic reinforcement materials were also used as surface layers for coating of WPC (Schmidt et al., 2013). One of them was TWINTEX (reinforcement fabric of commingled thermoplastic and glass filaments), the second one was S-TEX (glass fabric reinforced polypropylene laminate with randomly oriented glass fibers).

However, only a few studies were carried out for surface coating of flat pressed WPC (Schmidt et al., 2013). Physical and mechanical properties of WPC can be improved by coating of their surface with different coating materials and this can expand the field of their applications. Therefore, the objective of this study was to investigate the effects of different kinds of coating materials on the properties of flat-pressed WPC panels.

\section{MATERIALS AND METHODS} 2. MATERIJALI I METODE

The particles of recycled polyethylene (rPE) and wood with moisture content of 2-3\% were used in this study for making WPC panels. The particles are shown in Figure 1 and their fraction analysis is presented in Table 1.

The ratio of wood particles to rPE was 60:40. Wood particles and rPE (in the natural dry state) were mixed by hand for 10 minutes. The coating was made from one or two surface sides of WPC panel. Two groups of coating materials were used: natural veneer - the rotary-cut birch veneer and sliced oak veneer; and synthetic materials - phenolic impregnated paper, PE film and rPE layer.

Process of one-side coating (Figure 2a). The rotary-cut birch veneer, sliced oak veneer, phenolic impregnated paper, PE film or rPE layer was put into open press-form. Then the mat was formed from the woodpolymer mixture in an open press-form and transferred to the hot press.

Process of two-side coating (Figure 2b). The lower layer of the rotary-cut birch veneer, sliced oak veneer, phenolic impregnated paper, $\mathrm{PE}$ film or rPE layer was put into open press-form. Then the mat was formed from the wood-polymer mixture into an open press-form. After that, the outer layer of the rotary-cut birch veneer, sliced oak veneer, phenolic impregnated paper, PE film or rPE layer was put on the prepared composition. Then this sandwich packet was transferred to the hot press. 
Table 1 Fraction analysis (by \% weight)

Tablica 1. Analiza frakcija (\% mase)

\begin{tabular}{|l|c|c|c|c|c|c|c|}
\hline \multirow{2}{*}{$\begin{array}{l}\text { Components } \\
\text { Sastavnice }\end{array}$} & \multicolumn{7}{|c|}{ Screen hole size, $\mathbf{m m} /$ Veličina otvora sita, $\mathrm{mm}$} \\
\cline { 2 - 9 } & $-/ 5$ & $5 / 4$ & $4 / 2$ & $2 / 1$ & $1 / 0.63$ & $0.63 / 0.315$ & $0.315 / 0$ \\
\hline Wood particles / drvno iverje & 4.75 & 12.2 & 15.79 & 40.28 & 15.67 & 9.13 & 2.18 \\
\hline rPE / reciklirani polietilen & 9.53 & 3.04 & 53.14 & 32.45 & 1.83 & - & - \\
\hline
\end{tabular}

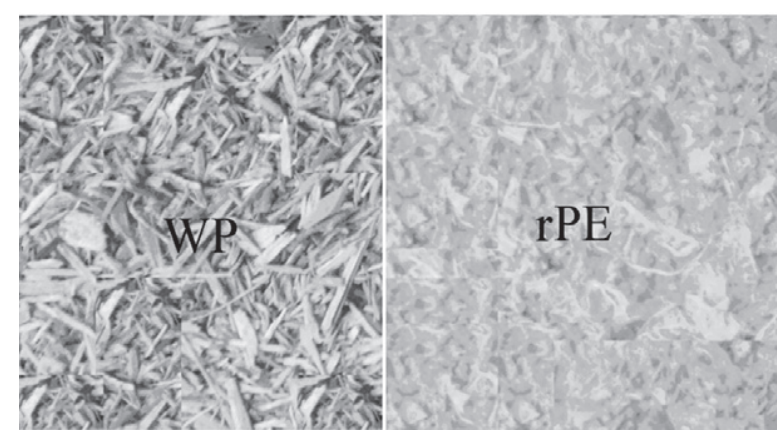

Figure 1 Wood particles (WP) and recycled polyethylene (rPE)

Slika 1. Drvno iverje (WP) i reciklirani polietilen (rPE)

The size of all manufactured WPC test panels was $250 \mathrm{~mm}$ in length and $230 \mathrm{~mm}$ in width, and $8.0 \mathrm{~mm}$ in thickness. All manufactured WPC panels were made in the laboratory press. The hot press was operated in plate position control mode, with the pressure limited to a maximum of $3.5 \mathrm{MPa}$. The pressing temperature was $180^{\circ} \mathrm{C}$ and pressing time was $8.0 \mathrm{~min}$. At the end of the press cycle, the WPC panels were removed from the press for cooling to the temperature of $30-40{ }^{\circ} \mathrm{C}$. The density of non-coated WPC panels was $800 \mathrm{~kg} / \mathrm{m}^{3}$. Noncoated WPC panels were manufactured at the same pressing parameters (Lyutyy et al., 2014).

Modulus of rupture (MOR) and water resistance (thickness swelling (TS) and water absorption (WA)) of the panels were evaluated according to EN 310 and EN 317, respectively.

The analysis of variance (ANOVA) was conducted to study the effect of different kinds of coating materials (rotary-cut birch veneer, sliced oak veneer, phenolic impregnated paper, PE film and rPE layer) and the type of coating (one or two-side) on the modulus of rupture, thickness swelling and water absorption of coated WPC panels at a 0.05 significance level. Duncan's multiple range tests were conducted for multiple comparisons between the means of the measured properties for different kinds of coating materials and different types of coating.

\section{RESULTS AND DISCUSSION} 3. REZULTATI I RASPRAVA

ANOVA showed that the kind of coating materials and the type of coating significantly influenced MOR, TS and WA. All investigated coating materials lead to the increase of the MOR of coated WPC panels (Table 2 and 3). The highest values of MOR were observed in WPC panels coated with rotary-cut birch veneer. In particular, the MOR of one-side coated WPC panels with rotary-cut birch veneer increased in 4.9-6.0 times in along veneer fibers and in 1.6-1.7 times in across veneer fibers depending on the coating location (up or down) during the test. Slightly lower values of MOR (in 4.3-5.3 times in along veneer fibers and in 1.5 times in across veneer fibers) were observed in oneside coated WPC panels with sliced oak veneer. The higher values of MOR in one-side coated WPC panels with sliced veneer were obtained in the work (Norvyda and Minelga, 2006). This can be explained by higher initial MOR of non-coated WPC panels and the use of five layers of veneer for coating of WPC panels except for one layer as in our case.

MOR of WPC panels coated with phenolic impregnated paper was increased in 1.7 times and for WPC panels coated with PE film and rPE layer in 2.02.2 and about 1.8 times, respectively.

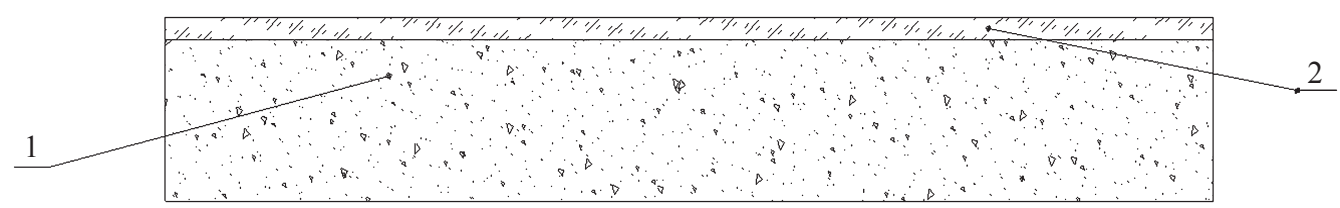

(a)

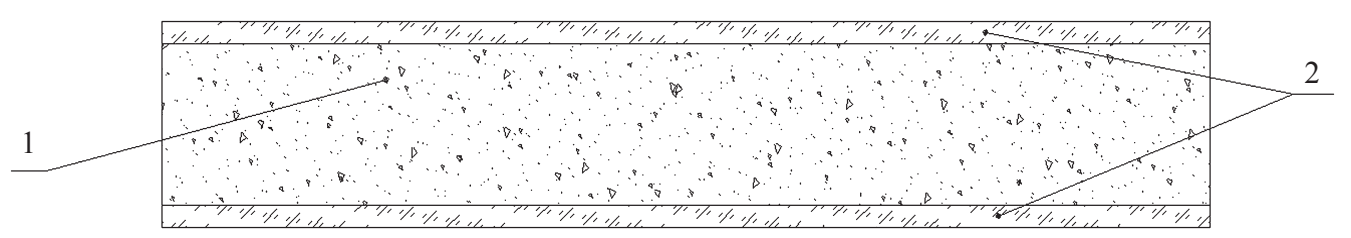

(b)

Figure 2 Coated flat pressed WPC: (a) - one-side coated; (b) - two-side coated: 1 - WPC composition; 2 - coating material (rotary-cut birch veneer, sliced oak veneer, phenolic impregnated paper, PE film or rPE layer)

Slika 2. Obložena WPC ploča: a) jednostrano obložena, b) dvostrano obložena, 1 - WPC kompozit, 2 - materijal za oblaganje (ljušteni brezov furnir, rezani hrastov furnir, fenolni impregnirani papir, polietilenska folija, reciklirani polietilenski sloj) 
Table 2 Properties of one and two-side coated WPC panels with rotary-cut birch and sliced oak veneers

Tablica 2. Svojstva jednostrano i dvostrano obložene WPC ploče ljuštenim brezovim furnirom i rezanim hrastovim furnirom

\begin{tabular}{|c|c|c|c|c|c|c|c|}
\hline \multirow{3}{*}{$\begin{array}{c}\text { Property } \\
\text { Svojstvo }\end{array}$} & \multirow{3}{*}{$\begin{array}{l}\text { Control } \\
\text { Kontrolni } \\
\text { uzorak }\end{array}$} & \multicolumn{4}{|c|}{ One-side / Jednostrano } & \multicolumn{2}{|c|}{ Two-side / Dvostrano } \\
\hline & & \multicolumn{2}{|c|}{$\begin{array}{l}\text { Rotary-cut birch veneer } \\
\text { Ljušteni brezov furnir }\end{array}$} & \multicolumn{2}{|c|}{$\begin{array}{l}\text { Sliced oak veneer } \\
\text { Rezani hrastov furnir }\end{array}$} & \multirow{2}{*}{$\begin{array}{c}\text { Rotary-cut } \\
\text { birch veneer } \\
\text { Ljušteni brezov } \\
\text { furnir }\end{array}$} & \multirow{2}{*}{$\begin{array}{c}\text { Sliced oak } \\
\text { veneer } \\
\text { Rezani hrastov } \\
\text { furnir }\end{array}$} \\
\hline & & $\begin{array}{l}\text { Veneer up } \\
\text { furnir je s } \\
\text { gornje } \\
\text { strane }\end{array}$ & $\begin{array}{l}\text { Veneer down } \\
\text { furnir jes } \\
\text { donje strane }\end{array}$ & $\begin{array}{l}\text { Veneer up } \\
\text { furnir je } s \\
\text { gornje strane }\end{array}$ & $\begin{array}{l}\text { Veneer down } \\
\text { furnir je s } \\
\text { donje strane }\end{array}$ & & \\
\hline $\begin{array}{l}\text { MOR, } \\
\mathrm{MPa}\end{array}$ & $5.6(0.43) a$ & $27.4 \frac{(0.62) c}{9.5(0.38) d}$ & $\frac{33.6(0.56) f}{9.2(0.51) c d}$ & $24.2 \frac{(0.29) b}{8.6(0.16) b}$ & $\begin{array}{l}29.5(0.32) d \\
8.7(0.17) b c\end{array}$ & $\begin{array}{l}48.2 \underline{(1.61) g} \\
12.7(0.55) e\end{array}$ & $\frac{31.1(0.88) e}{9.1(0.88) b c d}$ \\
\hline WA, $\%$ & $23.5(1.30) a$ & \multicolumn{2}{|c|}{$35.7(1.9) c$} & \multicolumn{2}{|c|}{$31.1(1.3) b$} & $37.0(1.75) c d$ & $38.6(3.73) d$ \\
\hline TS, $\%$ & $10.1(0.69) a$ & \multicolumn{2}{|c|}{$18.7(2.2) c$} & \multicolumn{2}{|c|}{$15.4(1.5) b$} & $19.2(2.30) c$ & $21.8(2.60) d$ \\
\hline
\end{tabular}

Key / Legenda: MOR - modulus of rupture / modul loma (MPa); WA - water adsorption / upijanje vode (\%); TS - thickness swelling / debljinsko bubrenje $(\%)$

*Values in parenthesis are standard deviations based on twelve samples. / Vrijednosti u zagradama standardne su devijacije na temelju 12 uzoraka.**Different letters denote a significant difference. / Različita slova označuju značajnu razliku. ***The numerator shows the value of MOR along veneer fibers, and the denominator - across veneer fibers. / Brojnik pokazuje vrijednost modula loma uzduž vlakanaca furnira, a nazivnik okomito na njih.

The similar results were found in the work (Borysiuk et al., 2011); for example, the coated particleboards showed variable MOR and MOE parameters depending on testing direction (along or across the outer layer veneers). Application of veneers to outer layers strengthened the boards in major axis (MOR and MOE gained around $65 \div 72 \%$ ) with simultaneous drop in minor axis (by around $23 \div 30 \%$ ).

The same results were observed in the work (Schmidt et al., 2013). The reinforcement of WPC panels with TWINTEX in a single step process leads to 2.4 (4.0) times higher MOE (MOR) in comparison with the unreinforced reference panel. Surface reinforced panels by use of S-TEX show 3.4 (5.6) times higher MOE (MOR). Moreover, the value of MOR of WPC panels coated with TWINTEX was $62.2 \mathrm{MPa}$ and when coated with S-TEX the value of MOR was 89.7 $\mathrm{MPa}$. Such higher values of MOR can be explained by the higher strength of TWINTEX and S-TEX core materials. In particular, the MOR of TWINTEX (in trans- verse direction) and S-TEX (in longitudinal direction) is 50 and $125 \mathrm{MPa}$, respectively. S-TEX reinforced material has higher flexural properties than TWINTEX reinforced material because of higher nominal weight and glass content.

MOR of two-side coated WPC panels increased significantly in comparison with one-side coated panels. The values of MOR in two-side coated WPC panels with rotary-cut birch veneer were increased in 8.4 times in along veneer fibers and in 2.3 times in across veneer fibers. Coating of WPC panels with sliced oak veneer also resulted in higher values of MOR; for example, MOR was increased in 5.5 times in along veneer fibers and 1.6 in across veneer fibers. The MOR of WPC panels coated with phenolic impregnated paper and PE film or rPE layer was increased by $79 \%$ and $135 \%$, respectively.

It should also be noted that WPC panels coated with natural veneers (rotary-cut birch veneer or sliced oak veneer) had higher values of strength properties in

Table 3 Properties of one and two-side coated WPC panels with phenolic impregnated paper, PE film or rPE layer

Tablica 3. Svojstva jednostrano i dvostrano obložene WPC ploče fenolnim impregniranim papirom, polietilenskom folijom i recikliranim polietilenskim slojem

\begin{tabular}{|c|c|c|c|c|c|c|c|c|c|c|}
\hline \multirow{3}{*}{$\begin{array}{l}\text { Property } \\
\text { Svojstvo }\end{array}$} & \multirow{3}{*}{$\begin{array}{c}\text { Control } \\
\text { Kon- } \\
\text { trolni } \\
\text { uzorak }\end{array}$} & \multicolumn{6}{|c|}{ One-side / Jednostrano } & \multicolumn{3}{|c|}{ Two-side / Dvostrano } \\
\hline & & \multicolumn{2}{|c|}{$\begin{array}{c}\text { Phenolic } \\
\text { impregnated } \\
\text { paper } \\
\text { Fenolni impregni- } \\
\text { rani papir } \\
\end{array}$} & \multicolumn{2}{|c|}{$\begin{array}{c}\text { PE film } \\
\text { Polietilenska folija }\end{array}$} & \multicolumn{2}{|c|}{$\begin{array}{c}\text { rPE layer } \\
\text { Reciklirani } \\
\text { polietilenski sloj }\end{array}$} & \multirow{2}{*}{$\begin{array}{c}\text { Phenolic } \\
\text { impreg- } \\
\text { nated } \\
\text { paper } \\
\text { Fenolni } \\
\text { impregni- } \\
\text { rani } \\
\text { papir }\end{array}$} & \multirow{2}{*}{$\begin{array}{l}\text { PE film } \\
\text { Poli- } \\
\text { etilenska } \\
\text { folija }\end{array}$} & \multirow{2}{*}{$\begin{array}{c}\text { rPE } \\
\text { layer } \\
\text { Recikli- } \\
\text { rani } \\
\text { poli- } \\
\text { etilenski } \\
\text { sloj }\end{array}$} \\
\hline & & $\begin{array}{l}\text { Paper } \\
\text { up } \\
\text { papir je } \\
\text { s gornje } \\
\text { strane }\end{array}$ & $\begin{array}{c}\text { Paper } \\
\text { down } \\
\text { papir je } \\
\text { s donje } \\
\text { strane }\end{array}$ & $\begin{array}{l}\text { Film up } \\
\text { folija je } \\
\text { s gornje } \\
\text { strane }\end{array}$ & $\begin{array}{c}\text { Film } \\
\text { down } \\
\text { folija je s } \\
\text { donje } \\
\text { strane }\end{array}$ & $\begin{array}{l}\text { Layer } \\
\text { up } \\
\text { sloj je s } \\
\text { gornje } \\
\text { strane }\end{array}$ & $\begin{array}{l}\text { Layer } \\
\text { down } \\
\text { slojje s } \\
\text { donje } \\
\text { strane }\end{array}$ & & & \\
\hline MOR, MPa & $\begin{array}{c}5.6 \\
(0.43) a \\
\end{array}$ & $\begin{array}{c}9.1 \\
(0.72) b\end{array}$ & $\begin{array}{c}9.5 \\
(0.56) b c\end{array}$ & $\begin{array}{c}11.5 \\
(0.49) e\end{array}$ & $\begin{array}{c}12.3 \\
(0.20) f\end{array}$ & $\begin{array}{c}10.3 \\
(0.53) d\end{array}$ & $\begin{array}{c}10.0 \\
(0.58) c d\end{array}$ & $\begin{array}{c}10.0 \\
(0.64) c d\end{array}$ & $\begin{array}{c}13.4 \\
(0.84) \mathrm{g}\end{array}$ & $\begin{array}{c}13.2 \\
(0.61) \mathrm{g} \\
\end{array}$ \\
\hline WA, \% & $\begin{array}{c}23.5 \\
(1.30) e \\
\end{array}$ & \multicolumn{2}{|c|}{$\begin{array}{c}25.5 \\
(1.7) f\end{array}$} & \multicolumn{2}{|c|}{$\begin{array}{c}17.5 \\
(1.9) c \\
\end{array}$} & \multicolumn{2}{|c|}{$\begin{array}{c}19.6 \\
(1.35) d\end{array}$} & $\begin{array}{c}23.3 \\
(1.65) e \\
\end{array}$ & $\begin{array}{c}12.9 \\
(1.32) b\end{array}$ & $\begin{array}{c}6.9 \\
(0.97) a \\
\end{array}$ \\
\hline $\mathrm{TS}, \%$ & $\begin{array}{c}10.1 \\
(0.69) c\end{array}$ & \multicolumn{2}{|c|}{$\begin{array}{l}14.2 \\
(1.8) e\end{array}$} & \multicolumn{2}{|c|}{$\begin{array}{l}10.0 \\
(1.2) c\end{array}$} & \multicolumn{2}{|c|}{$\begin{array}{c}13.0 \\
(1.7) d\end{array}$} & $\begin{array}{c}8.6 \\
(0.98) b \\
\end{array}$ & $\begin{array}{c}9.2 \\
(0.93) b c\end{array}$ & $\begin{array}{c}5.8 \\
(0.80) a\end{array}$ \\
\hline
\end{tabular}

Key / Legenda: MOR - modulus of rupture / modul loma (MPa); WA - water adsorption / upijanje vode (\%); TS - thickness swelling / debljinsko bubrenje $(\%)$

*Values in parenthesis are standard deviations based on twelve samples. / Vrijednosti u zagradama standardne su devijacije na temelju 12 uzoraka.**Different letters denote a significant difference. / Različita slova označuju značajnu razliku. 
... Bekhta, Lyutyy, Ortynska: Effects of Different Kinds of Coating Materials on Properties...

Table 4 Duncan's test results for main effects

Tablica 4. Rezultati Duncanova testa

\begin{tabular}{|c|c|c|c|c|c|c|c|c|}
\hline \multirow[t]{2}{*}{$\begin{array}{c}\text { Main factors } \\
\text { Utjecajni činitelji }\end{array}$} & \multicolumn{2}{|c|}{$\begin{array}{l}\text { MOR (along } \\
\text { fibers), MPa } \\
M O R(u z d u z ̌ \\
\text { vlakanaca), } \\
M P a\end{array}$} & \multicolumn{2}{|c|}{$\begin{array}{c}\text { MOR (across } \\
\text { fibers), MPa } \\
\text { MOR } \\
\text { (poprečno na } \\
\text { vlakanca), } \\
M P a\end{array}$} & \multicolumn{2}{|c|}{ WA, \% } & \multicolumn{2}{|c|}{ TS, $\%$} \\
\hline & Mean & SG & Mean & SG & Mean & SG & Mean & $\mathrm{SG}$ \\
\hline \multicolumn{9}{|l|}{ Material / Materijal } \\
\hline control (non-coated) / kontrolni uzorak (neobloženi) & 5.56 & $\mathrm{a}$ & 5.56 & $\mathrm{a}$ & 23.47 & $\mathrm{~b}$ & 10.11 & $\mathrm{~b}$ \\
\hline rotary-cut birch veneer / ljušteni brezov furnir & 36.21 & $\mathrm{f}$ & 10.49 & $\mathrm{~d}$ & 36.36 & $\mathrm{~d}$ & 18.99 & $\mathrm{~d}$ \\
\hline sliced oak veneer / rezani hrastov furnir & 28.24 & e & 8.78 & $\mathrm{~b}$ & 34.81 & $\mathrm{c}$ & 17.98 & $\mathrm{~d}$ \\
\hline phenolic impregnated paper / fenolni impregnirani papir & 9.65 & $\mathrm{~b}$ & 9.65 & $\mathrm{c}$ & 24.36 & $\mathrm{~b}$ & 11.66 & $\mathrm{c}$ \\
\hline PE film / polietilenska folija & 12.70 & $\mathrm{~d}$ & 12.70 & $\mathrm{f}$ & 15.20 & $\mathrm{a}$ & 9.70 & $\mathrm{ab}$ \\
\hline rPE layer / reciklirani polietilenski sloj & 11.66 & $\mathrm{c}$ & 11.66 & $\mathrm{e}$ & 14.50 & $\mathrm{a}$ & 8.98 & $\mathrm{a}$ \\
\hline \multicolumn{9}{|l|}{ Type of coating / vrsta oblaganja } \\
\hline control (non-coated) / kontrolni uzorak (neobloženi) & 5.56 & $\mathrm{a}$ & 5.56 & $\mathrm{a}$ & 23.47 & $\mathrm{a}$ & 10.11 & $\mathrm{a}$ \\
\hline one-side coating / jednostrano oblaganje & 17.68 & $\mathrm{~b}$ & 9.85 & $\mathrm{~b}$ & 25.85 & $\mathrm{~b}$ & 14.20 & $\mathrm{c}$ \\
\hline two-side coating / dvostrano oblaganje & 18.55 & $\mathrm{c}$ & 11.84 & $\mathrm{c}$ & 24.93 & $\mathrm{~b}$ & 12.90 & $\mathrm{~b}$ \\
\hline
\end{tabular}

*SG - statistical group / statistička skupina; **Different letters denote a significant difference. / Različita slova označuju značajnu razliku.

comparison with the using of synthetic materials (phenolic impregnated paper, PE film or rPE layer). In particular, the MOR values of two-side coated WPC panels were in 4.7 times higher using rotary-cut birch veneer (in along veneer fibers) in comparison with the using of phenolic impregnated paper and in 3.6 times higher in comparison with the using of PE film or $\mathrm{PPE}$ layer. Such dependencies could be explained by the properties of coating materials. The strength values of coating materials are quite different. In particular, for birch and oak wood with moisture content of $12 \%$, the MOR is in the range of 56-117 MPa and 75-125 MPa, respectively, and it should also be taken into account that these values depend on the conditions of tree growth (Green et al., 1999). Moreover, the thickness of the coating material should be considered; the rotary-cut birch veneer with the thickness of $1.5 \mathrm{~mm}$, sliced oak veneer with the thickness of $0.5 \mathrm{~mm}$, and PE film with the thickness of $0.1 \mathrm{~mm}$ and impregnated phenolic paper with gramature only $80 \mathrm{~g} / \mathrm{m}^{2}$ were used in this study.

The highest water resistance was observed in WPC panels coated with rPE layer. The coating of WPC with natural veneers also resulted in the increasing of TS and WA in comparison with non-coated WPC panels. It was found that coating with rotary-cut birch veneer and sliced oak veneer caused the increasing of TS (WA) on 57 (90) \% and 64 (115) \%, respectively, in comparison with non-coated WPC panels. It should also be noted that water resistance of one-side coating with natural veneer was higher than two-side coating with natural veneer. The values of water resistance of WPC panels coated with natural veneer were lower in comparison with synthetic materials, which could be explained by higher water absorption of wood veneer. The similar results were observed in the work (Istek et al., 2010). The minimum values of WA and TS at 2 and 96 hours were obtained as $56.7 \%$ and $81.4 \%$ in white oak-UF, $11.1 \%$ in common maple-UF, and $14.8 \%$ in white oak-UF (Istek et al., 2010) The higher TS and WA values of $21.8 \%$ and $38.6 \%$, respectively, were reported in another work (Borysiuk et al., 2011).

It was found that one-side coating of WPC with phenolic impregnated paper leads to the increasing of TS and WA. In contrast, two-side coating of WPC with phenolic impregnated paper, PE film or rPE layer leads to the decreasing of WA and TS. In particular, the TS (WA) was decreased by 13 (1) \% with using phenolic impregnated paper; by 10 (45) \% with using PE film and by 46 (68) \% with using rPE layer in comparison with non-coated WPC. The polyethylene has high water resistance; its water absorption for 24 hours is $0.10 \%$. The polyethylene formed water resistance layer (film) on the surface of WPC. This layer does not allow WPC to absorb water and swell. Rotary-cut birch and sliced oak veneers are natural materials in contrast with polyethylene. They can absorb a lot of water, which leads to the increasing of TS and WA of WPC.

The results of Duncan's tests conducted to determine the significance of the relationships between the kind of coating materials, the type of coating and MOR, thickness swelling and water absorption are given in Table 4.

As shown in Table 4, differences in the MOR, TS and WA between all the investigated coating materials and types of coating were statistically significant.

\section{CONCLUSIONS 4. ZAKLJUČAK}

The values of MOR were increased in WPC panels coated with all investigated coating materials. The highest values of MOR were observed in WPC coated with rotary-cut birch and sliced oak natural veneer. It should be noted that the highest MOR was observed in WPC coated with natural veneer along the grain. WPC panels coated with phenolic impregnated paper, PE film or rPE layer had lower values of MOR in com- 
parison with WPC panels coated with natural veneer. Besides, the MOR was higher in two-side coated WPC panels with all investigated coating materials. The highest water resistance was observed in WPC panels coated with PE film or rPE layer. The coating with natural veneer leads to the decreasing of water resistance of WPC. Moreover, water resistance of one-side coated WPC panels with natural veneer was higher in comparison with two-sided coated WPC panels with natural veneer. The two-side coating of WPC panels with phenolic impregnated paper, PE film or rPE layer leads to the decreasing of WA and TS. As follows, coating materials that are widely used for coating of plywood, particleboards and fiberboards can be successfully used for coating of flat pressed WPC panels. Therefore, the results obtained in this study make it possible to expand the application of WPC panels and also provide important information for future research and use of such flat pressed coated WPC.

\section{REFERENCES}

\section{LITERATURA}

1. Ayrilmis, N.; Benthien, J. T.; Thoemen, H.; White, R. H., 2011: Properties of flat-pressed wood plastic composites containing fire retardants. Journal of Applied Polymer Science, 122: 3201-3210.

http://dx.doi.org/10.1002/app.34346.

2. Ayrilmis, N.; Benthien, J. T.; Thoemen, H.; White, R. H., 2012: Effects of fire retardants on physical, mechanical, and fire properties of flat-pressed WPCs. European Journal of Wood and Wood Products, 70: 215-224. http://dx.doi.org/10.1007/s00107-011-0541-3.

3. Ayrilmis, N.; Jarusombuti, S., 2011: Flat-pressed wood plastic composite as an alternative to conventional wood based panels. Journal of Composite Materials, 45: 103112. http://dx.doi.org/10.1177/0021998310371546.

4. Benthien, J. T.; Thoemen, H., 2012: Effects of raw materials and process parameters on the physical and mechanical properties of flat pressed WPC panels. Composites: Part A, 43 (3): 570-576.

http://dx.doi.org/10.1016/j.compositesa.2011.12.028.

5. Borysiuk, P.; Zbiec, M.; Boruszewski, P.; Maminski, M.; Mazurek, A., 2011: Possibilities of single-stage pressing of veneered particleboards. Annals of Warsaw University of Life Sciences - SGGW Forestry and Wood Technology, 73: 172-175.

6. Buzarovska, A.; Bogoeva-Gaceva, G.; Grozdanov, A.; Avella, M.; Gentile, G.; Errico, M., 2008: Potential use of rice straw as filler in eco-composite materials. Australian Journal of Crop Science, 1(2): 37-42.

7. Eder, A., 2010: Wood-plastic composite markets in Europe: presentation. The Fourth China International Summit of WPC, $22 \mathrm{p}$.

8. Green, D. W.; Winandy, J. E.; Kretschmann, D. E., 1999: Mechanical properties of wood. In : Wood handbook Wood as an engineering material, pp. 4-44.

9. Istek, A.; Aydemir, D.; Aksu, S., 2010: The effect of décor paper and resin type on the physical, mechanical, and surface quality properties of particleboards coated with impregnated décor paper. BioResources, 5 (2): 1074-1083.
10. Kargarfard, A.; Jahan-Latibari, A., 2012: Application of recycled polyethylene in combination with Urea-Formaldehyde resin to produce water resistant particleboard. Proceedings of the 55th International Convention of Society of Wood Science and Technology August 27-31, Beijing, China, pp. 1-7.

11. Klyosov, A. A., 2007: Wood Plastic Composites. New Jersey: John Wiley \& Sons, Hoboken, 726 p. http://dx.doi.org/10.1002/9780470165935.

12. Lindfors, N. C.; Salo, J., 2012: A novel nontoxic wood-plastic composite cast. The Open Medical Devices Journal, 4: 1-5. http://dx.doi.org/10.2174/1875181401204010001.

13. Lyutyy, P.; Bekhta, P.; Sedliacik, J.; Ortynska, G., 2014: Properties of flat-pressed wood-polymer composites made using secondary polyethylene. Acta Facultatis Xylologiae Zvolen, 56 (1): 39-50.

14. Moldovan, A.; Patachia, S.; Buican, R.; Tieren, M. H., 2012: Characterization of polyefins wastes by FTIR spectroscopy. Bulletin of the Transilvania University of Brasov Series I: Engineering Sciences, 5 (2): 65-72.

15. Norvydas, V.; Minelga, D., 2006: Strength and stiffness properties of furniture panels covered with different coatings. Materials Science (MEDŽIAGOTYRA), 12 (4): 328-332.

16. Sardashti, A., 2009: Wheat straw-clay-polypropylene hybrid composites. Master of Applied Science thesis, University of Waterloo, $163 \mathrm{p}$.

17. Segerholm, K., 2012: Characteristics of wood plastic composites based on modified wood-moister properties, biological resistance and micromorphology. Doctoral Thesis KTH Building Materials Technology, Stockholm, Sweden, $66 \mathrm{p}$.

18. Segerholm, K., 2007: Wood plastic composites made from modified wood. Licentiate Thesis in Building Materials Technology. Stockholm, Sweden, 23 p.

19. Schmidt, H.; Benthien, J. T.; Thoemen, H., 2013: Processing and flexural properties of surface reinforced flat pressed WPC panels. European Journal of Wood and Wood Products, 71: 591-597. http://dx.doi.org/10.1007/s00107-013-0719-y.

20. Thoemen, H.; Irle, M.; Sernek, M., 2010: Wood-based panels - an introduction for specialists. Brunel University Press, London, $152 \mathrm{p}$.

21. Yao, F., 2008: Rice Straw Fiber Polymer Composites: Thermal and mechanical performance. Thermal and mechanical performance. Dissertation, Louisiana State University and Agricultural and Mechanical College, $187 \mathrm{p}$.

22. Winandy, J. E.; Stark, N. M.; Clemons, C. M., 2004: Considerations in recycling of wood-plastic composites. $5^{\text {th }}$ Global Wood and Natural Fibre Composites Symposium, A6-1-A6-9.

\section{Corresponding address:}

\section{PAVLO LYUTYY, Ph.D.}

Department of Wood-Based Composites

National University of Forestry \& Wood Technology of Ukraine

Gen.Chuprynky 103

79057 Lviv, UKRAINE

e-mail: pawa_lyutyj@ukr.net 